\title{
Effect of Application of Farmyard Manure and Gypsum on Saline Sodic Soils of Raya Alamata District, Northern Ethiopia
}

\author{
Birhane Hailu and Hagos Mehari \\ Ethiopian Institute of Agricultural Research, Mekhoni Agricultural Research Center, Mekhoni, Ethiopia
}

\begin{abstract}
A field experiment was conducted in Raya Alamata district, northern Ethiopia to investigate the effect of sole and combined application of FYM and gypsum on saline sodic soils on yield of sorghum by supplying different rates of farmyard manure $(\mathrm{FYM})$ and/or gypsum $(\mathrm{CaSO} 4.2 \mathrm{H} 2 \mathrm{O})$ application alone or both mixtures using a randomized complete block design for three consecutive years. The treatment used included: control, three FYM rates alone, two gypsum rates alone and six combination of FYM and gypsum with a total of 12 treatments. Each treatment was replicated three times to yield 36 experimental plots. The result indicated that, there was no significant difference between treatments in the first and second year of cropping season. However, the effect the amendments were shown in the third year of the cropping season, and hence, the treatment effect of the combined application of FYM and gypsum were more effective and improved soil properties and increased the yield of sorghum. In addition, compared to all other treatments, the combined application of 4 tha $^{-1} \mathrm{FYM}^{+}$ $100 \%$ GR followed by 8 tha $^{-1}$ FYM $+100 \%$ GR resulted the highest grain yield of sorghum and reduced the sodium induced hazards than all other treatments. Hence, it is recommended as the best treatment in the improvement of saline sodic soils of the district.
\end{abstract}

Keywords: Gypsum; Farmyard manure; Sorghum; Soil amendment; Soil properties

DOI: $10.7176 / J N S R / 12-22-02$

Publication date: November $30^{\text {th }} 2021$

\section{Introduction}

Salt affected soils are characterized by excessively high levels of water-soluble salts, including sodium chloride, sodium sulfate, calcium chloride and magnesium chloride (Suriyan etal.,2011). Saline sodic soils are a major environmental issue and a great concern in the modern world as they significantly limit plant growth and development (Qadir et al., 2008; Sadiq et al., 2007). Saline sodic soils are containing both excessive quantities of soluble salts and exchangeable $\mathrm{Na}$ and interfere with the growth and production of most crop plants (USSLS, 1954). These soils form as a result of the combined processes of salinization and alkalization. Such accumulation of salts in the soils may alter its physical and chemical properties, including soil structure and hydraulic conductivity (Birhane, 2018; Mullins et al., 1990). If attempts are made to leach out the soluble salts of salinesodic soils with good quality irrigation water, the exchangeable $\mathrm{Na}$ levels and also $\mathrm{pH}$ would increase and, therefore, the soil would change to adverse characteristics of sodic soils. Therefore, attention must first be given to reducing the levels of exchangeable $\mathrm{Na}$ and then to the problem of excess soluble salts (Cheraghi et al., 2006).

There are many procedures that can be used to improve salt affected soils, such as, water leaching, chemical remediation and phytoremediation. The remediation of saline sodic soil using gypsum (CaSO4 2H2O) and farmyard manure (FYM) is a fruitful topic of investigation, being low cost, effective and simple to implement (Makoi and Verplancke, 2010). The physical, chemical and biological properties of salt affected soils are improved by the application of gypsum and/or FYM as remediation for sustainable land usage and crop productivity, leading to enhanced plant growth and development (Suriyan etal., 2011). Different findings (FAO,1988; Makoi and Ndakidemi, 2007) showed that, a combination of FYM and gypsum on saline sodic soils was found to be most important on improving cereal yields and effective tools for maintaining soil productivity. The concentration of exchangeable $\mathrm{Na}$, which was an indicator of sodic soil in raya Alamata district was higher in the soil and hence, continuous assessment and monitoring should be implemented to avoid the occurrence of soil sodicity and selection of suitable plants that can tolerate soil salinity/sodicity in necessary (Birhane et al., 2019).

In Ethiopia sorghum is grown in almost all regions occupying an estimated total land area of 1.83 million ha and its national average productivity of $2.37 \mathrm{tha}^{-1}$ (CSA, 2015). However, the productivity of sorghum is low due to biotic and edaphic factors affecting directly and indirectly (Tekle and Zemach, 2014). Hence, the aim of the present study was to investigate the effect of sole and combined application of FYM and gypsum on saline sodic soils on yield of sorghum and to remediate saline sodic soil using gypsum and/or farmyard manure.

\section{MATERIALS AND METHODS}

\subsection{Description of the Study Area}

\subsubsection{Location}

The study was conducted at Raya Alamata district in southern zone of Tigray, Regional State, northern Ethiopia. 
It is located $600 \mathrm{Km}$ north of Addis Ababa and about $182 \mathrm{Km}$ south of Mekelle, the capital city of the National Regional State of Tigray. Geographically, the experimental site is located between $12^{\circ} 25^{\prime}$ to $12^{\circ} 55^{\prime} \mathrm{N}$ latitude and $39^{\circ} 33^{\prime}$ to $39^{\circ} 53^{\prime} \mathrm{E}$ longitude with an altitude of 1522 meters above sea level. From the hydrological point of view, the site is located within the Afar drainage basin.

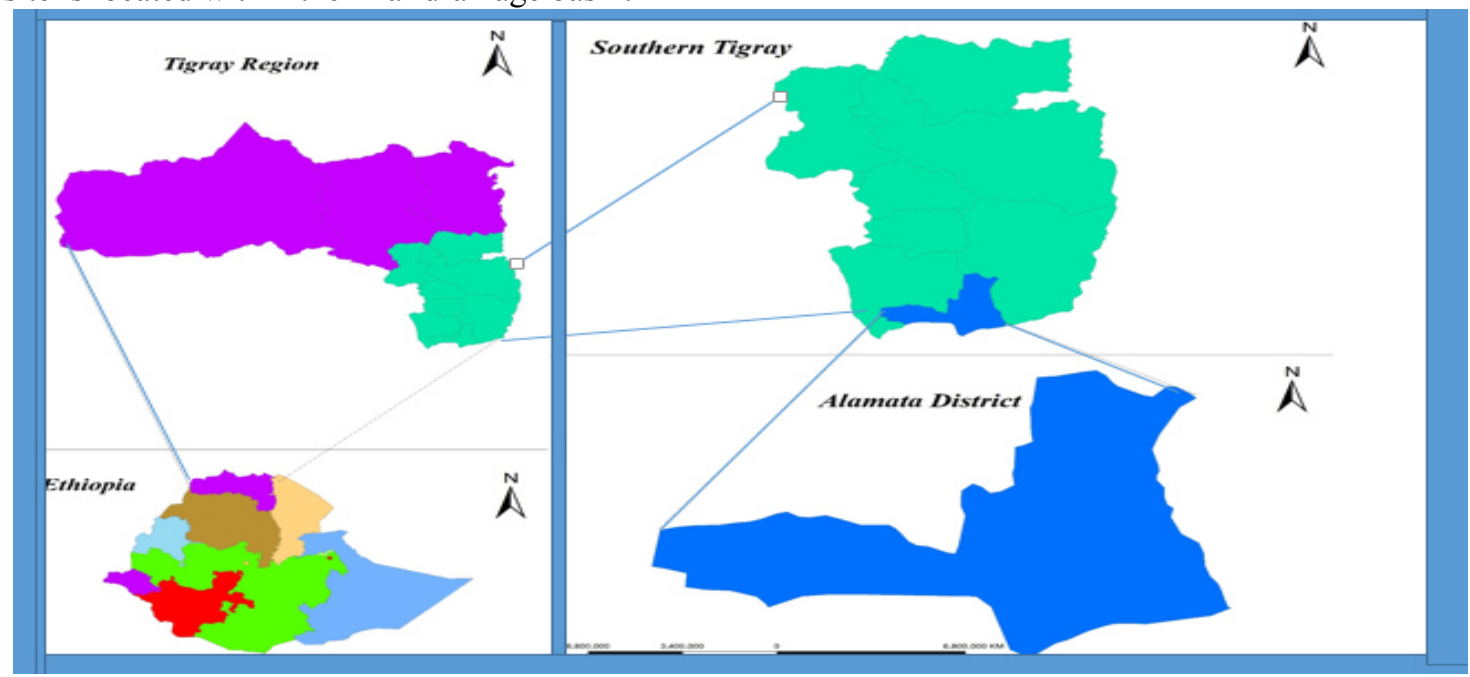

\subsubsection{Climate}

Figure 1. Location map of the district area.

The district is characterized as semi-arid climate region. The mean monthly minimum and maximum temperatures during the study period were $14.34{ }^{\circ} \mathrm{C}$ and $30.04{ }^{\circ} \mathrm{C}$, respectively. The district has also unevenly distributed and erratic annual rainfall amount which ranges between 450 and $600 \mathrm{~mm}$ with most of the rain falling in July - August. Hence, recurrent drought and long dry spell, especially in the main season. The combined effect of high temperature and strong solar radiation caused the potential evapotranspiration to be very high and significantly exceeds the rainfall in all months (RVLZ, 2007).

\subsubsection{Soil and hydrogeology}

The major soil types found in the district are Cambisols, Fluvisols, Leptosols and Vertisols. Soil distribution follows the landscape configuration, where on the level land plain Vertisols and Fluvisols are the dominant and found extensively in farmlands (Amanuel et al., 2015). The valley of the study area is a flat plain dominated by deep to very deep undifferentiated alluvial, lacustrine and beach sediments. The valley floor is bounded on both west and the east directions characterized by highly fractured and weathered basaltic rocks, alkaline and transitional basalt flows mainly Ashange basalt (Nata et al., 2015). A groundwater resource is believed to be the huge water resource in the area. The dominant groundwater flow directions are north-south and west-east. The depth of groundwater varies from about $20 \mathrm{~m}$ in Waja and $60 \mathrm{~m}$ in Adis-Kigni (south) areas in the northern part of the project area. The quaternary sediments vary widely in grain size and dominantly deposited as fluvial processes (Tenalem et al., 2013).

\subsection{Soil Samples collection and Laboratory Analysis}

Soil samples from the surface $(0-30 \mathrm{~cm})$ were collected before the application of the amendments. Similarly, samples were collected after the application of the treatments from each experimental plots using auger in each cropping season for the determination of selected soil salinity/sodicity indicators. The collected soil samples were analyzed using the proper laboratory procedures.

\subsection{Experimental Design, Treatment Combinations and Agronomic Operations}

The experiment consisted of two factor amendments involving two gypsum rates (50\% GR and $100 \%$ GR), three rates of FYM ( 4 tha $^{-1}, 6$ tha $^{-1}$ and 8 tha $\left.^{-1}\right)$, and farmer practice as a control treatment were used (Table 1). 
Table 1. Treatment combinations of the experiment

\begin{tabular}{ll}
\hline Treatments & Treatment combinations \\
\hline Treatment 1 & Control \\
Treatment 2 & $50 \%$ GR \\
Treatment 3 & $100 \%$ GR \\
Treatments 4 & 4 tha $^{-1}$ FYM \\
Treatment 5 & 4 tha $^{-1}$ FYM $+50 \%$ GR \\
Treatment 6 & 4 tha $^{-1}$ FYM $+100 \%$ GR \\
Treatment 7 & 6 tha $^{-1}$ FYM \\
Treatment 8 & 6 tha $^{-1}$ FYM $+50 \%$ GR \\
Treatment 9 & 6 tha $^{-1}$ FYM $+100 \%$ GR \\
Treatment 10 & 8 tha $^{-1}$ FYM \\
Treatment 11 & 8 tha $^{-1}$ FYM $+50 \%$ GR \\
Treatment 12 & 8 tha $^{-1}$ FYM $+100 \%$ GR \\
\hline
\end{tabular}

Treatment 12

8 tha $^{-1}$ FYM $+100 \%$ GR

$\mathrm{GR}=$ Gypsum requirement; FYM $=$ Farm yard manure, tha $^{-1}=$ ton per hectare.

Gypsum was calculated according to the soil test value of gypsum requirement. Farmyard manure and gypsum alone and in various combinations were applied to the soil well before planting so as mix with the soil. Each treatment replicated three times to yield 36 experimental plots, assigned in randomized complete block design (RCBD). Sorghum (Sorghum bicolor L.) (Meko) variety was planted as a test crop by early June for three consecutive cropping seasons. Except the experimental treatment differences all the necessary management activities were carried out uniformly to all experimental plots. Finally when the crop was fully matured sorghum yields were harvested and trashed after the harvesting period and yield of sorghum was measured.

\subsection{Data collection and Statistical Analysis}

The collected data were analyzed using Statistical Analysis System (SAS) software version 9.1. Analysis of variance $(A N O V A)$ was assayed. Mean differences were also tested using Fisher's Protected LSD test at $\mathrm{P} \leq 5 \%$ level.

\section{RESULTS AND DISCUSSIONS}

\subsection{Selected chemical characteristics of soils prior to the application of treatments}

Soil samples were collected before the application of treatments and were analyzed in the laboratory for their selected soil salinity/sodicity indicators. Analytical results of soil reaction ( $\mathrm{pHe}$ ), electrical conductivity of the saturation paste extract (ECe), exchangeable cations and exchangeable sodium percentage (ESP) were used as important parameters to explain salinity/sodicity characteristics of the soils. Three classes of salt affected soils were defined based on their chemical properties, accounting for changes in ECe, pHe and ESP. Accordingly, a threshold value of $4 \mathrm{dS} \mathrm{m}^{-1}$ ECe was used to differentiate between saline and non-saline soils. Similarly, a threshold value $15 \%$ for ESP and 8.5 for $\mathrm{pHe}$ were used as criteria for grouping the soils in to different classes of salt affected soils (USSLS, 1954). Accordingly, the experimental site was classified as saline sodic soil (Table 2).

Table 2. Selected soil chemical characteristics prior to the application of treatments

\begin{tabular}{|c|c|c|c|c|c|c|c|}
\hline \multicolumn{8}{|c|}{ Soil parameters } \\
\hline \multirow{3}{*}{ Values } & $\mathrm{pHe}$ & $\mathrm{ECe}$ & $\mathrm{Ca}+\mathrm{Mg}$ & $\mathrm{Na}$ & $\mathrm{K}$ & \multirow[t]{2}{*}{$\operatorname{ESP}(\%)$} & \multirow[t]{2}{*}{ CEC (cmol (+) $\mathrm{kg}^{1}$} \\
\hline & \multicolumn{5}{|c|}{$\left(\mathrm{cmol}(+) \mathrm{kg}^{1}\right)$} & & \\
\hline & 8.53 & 4.18 & 39.96 & 9.8 & 0.99 & 20.16 & 49.06 \\
\hline
\end{tabular}

$\mathrm{pHe}=$ soil reaction, $\mathrm{ECe}=$ soil electrical conductivity, $\mathrm{ESP}=$ exchangeable sodium percentage, $\mathrm{CEC}=$ cation exchange capacity.

\subsection{Effect of FYM and Gypsum on Yield and Yield Components of Sorghum}

The statistical analysis of the first and second year data showed non-significant difference in all yield and yield components of sorghum. This showed that, all the amendments used either applied singly or in combination have not considerably increased the yield and yield attributes of sorghum. Indeed, this revealed that, the effect of treatments were not significantly effective in maintaining soil physical and chemical properties better than that of the control. The relatively no response of sorghum to FYM application may be attributed to its slow release of nutrients which decomposes over time (Haq et al. 2001) and that of gypsum to its low solubility (Ghafoor \& Muhammad, 1990). The decomposition of FYM was further aggravated due to dry spell prevailed during most part of the crop season (Haq et al. 2001).

In contrary to the first and second year, the treatment effect of the applied FYM and gypsum were more effective and decreased the adverse effects of sodium and exchangeable sodium percentage in the third year and showed significant difference $(\mathrm{P} \leq 0.05)$ on panicle length, biomass yield and grain yield. This response may be 
attributed to release of nutrients from FYM through decomposition and due to solubility of gypsum over the three years. Accordingly, the combined treatment of $4 \mathrm{t} \mathrm{ha}^{-1} \mathrm{FYM}+100 \%$ GR followed by $8 \mathrm{t} \mathrm{ha}^{-1} \mathrm{FYM}+100 \%$ GR had responded the highest sorghum grain yield (48.25 and $47.28 \mathrm{qt} \mathrm{ha}^{-1}$ ) respectively, compared to all other treatments specifically in the third year cropping season. On the other hand, the control treatment (without treatment with gypsum and FYM), had week effect and resulted in lowest (24.56 qt ha-1) grain yield (Table 3). It is evident from the data that, the amendments applied in combination have considerably increased the yield of sorghum compared to the sole application of FYM and gypsum.

Table 3. Third year yield and yield component results

\begin{tabular}{|c|c|c|c|c|c|c|c|c|}
\hline Treatments & $\mathrm{DE}$ & $\mathrm{SC}$ & $\mathrm{DH}$ & MD & $\mathrm{PH}(\mathrm{cm})$ & $\mathrm{PL}(\mathrm{cm})$ & By $\left(q t h^{-1}\right)$ & Gy $\left(\mathrm{qt} \mathrm{ha}^{-1}\right)$ \\
\hline Control & 10 & 47 & 66 & 115 & 151 & 23 & 74.53 & 24.56 \\
\hline $50 \% \mathrm{GR}$ & 9 & 54 & 67 & 120 & 158 & 24 & 94.90 & 32.20 \\
\hline $100 \%$ GR & 10 & 48 & 67 & 120 & 155 & 22 & 100.27 & 34.58 \\
\hline 4 tha $^{-1}$ FYM & 9 & 51 & 69 & 125 & 154 & 24 & 98.43 & 34.25 \\
\hline 4 tha $^{-1} \mathrm{FYM}+50 \% \mathrm{GR}$ & 8 & 52 & 67 & 122 & 158 & 22 & 105.11 & 38.04 \\
\hline 4 tha $^{-1}$ FYM $+100 \%$ GR & 8 & 48 & 67 & 133 & 158 & 29 & 153.81 & 48.25 \\
\hline 6 tha $^{-1}$ FYM & 8 & 49 & 70 & 134 & 153 & 22 & 102.64 & 35.11 \\
\hline 6 tha $^{-1}$ FYM $+50 \%$ GR & 8 & 50 & 67 & 120 & 153 & 22 & 152.84 & 45.88 \\
\hline 6 tha $^{-1}$ FYM $+100 \%$ GR & 9 & 48 & 68 & 126 & 149 & 25 & 172.43 & 47.17 \\
\hline 8 tha $^{-1}$ FYM & 7 & 51 & 68 & 118 & 157 & 22 & 162.84 & 44.80 \\
\hline 8 tha $^{-1}$ FYM $+50 \%$ GR & 10 & 47 & 68 & 121 & 155 & 24 & 172.86 & 46.74 \\
\hline 8 tha $^{-1}$ FYM $+100 \%$ GR & 9 & 51 & 60 & 125 & 157 & 27 & 177.38 & 47.28 \\
\hline $\mathrm{LSD}<0.05$ & NS & NS & NS & NS & NS & 1.87 & 4.68 & 1.30 \\
\hline $\mathrm{CV} \%$ & 19.05 & 9.47 & 2.49 & 8.48 & 3.22 & 4.79 & 2.11 & 1.92 \\
\hline
\end{tabular}

$\mathrm{DE}=$ Days to emergency, $\mathrm{SC}=$ Stand count, $\mathrm{DH}=$ Days to heading, $\mathrm{MD}=$ Maturity date, $\mathrm{PL}=$ panicle length, $\mathrm{PH}=$ Plant height, $\mathrm{By}=$ Biomass yield and $\mathrm{Gy}=$ Grain yield, $\mathrm{qt} \mathrm{ha}^{-1}=$ quintal per hectare, $\mathrm{NS}=$ no significance, $\mathrm{LSD}=$ least significant difference, $\mathrm{CV}=$ coefficient of variance.

Results recorded from the three consecutive years of combined analysis showed that, there were statistically significant difference among the treatments for the major parameters of both biomass yield and grain yield. Compared to all the other treatments considering the agronomic data 8 tha $^{-1} \mathrm{FYM}+100 \%$ GR followed by 4 tha ${ }^{-1}$ FYM $+100 \%$ GR resulted the highest biomass as well as grain yield of sorghum (Table 4). However, considering the amount of FYM which was applied within the difference of 4 tha $^{-1}$, had its own value of economic analysis even if the value of FYM was not measured in terms of Ethiopian birr (ETB) and FYM is not easily accessible to the farmers of the district. In addition to this, 4 tha $^{-1} \mathrm{FYM}+100 \% \mathrm{GR}$ was by far lowered (best amendment) the value of sodium and exchangeable sodium percentage compared to 8 tha $^{-1}$ FYM $+100 \%$ GR (Table 4). These results suggested that combined amendments of FYM and gypsum treatment were superior to all other treatments in their effect on increased sorghum yield and effectively remedy the saline sodic soil condition.

It is evident from the data that, the amendments applied in combination have considerably increased the yield of sorghum compared to the sole application of FYM and gypsum. Of all the treatments, combined application of the two amendments i.e.FYM@4 tha $\mathrm{h}^{-1}+$ gypsum @100\% of GR and FYM@8 $9 \mathrm{tha}^{-1}+$ gypsum@100\% of GR out yielded all others where 27.58\% and 33.60\% increase in yield over that of control

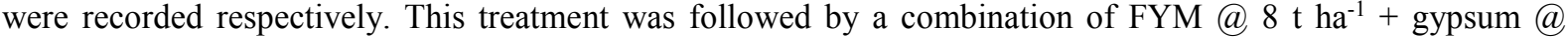
$100 \%$ of GR. 
Table 4. Three years combined analysis results of yield and yield components

\begin{tabular}{l} 
Treatments \\
\hline Control
\end{tabular}

\subsection{Effect of FYM and Gypsum on saline sodic soil characteristics}

A significant change in soil $\mathrm{pH}$ was observed due to the combined application of FYM and gypsum. This showed that, the combination of the two amendments have considerably decreased soil $\mathrm{pH}$ value. It was lowered from 8.53 to 7.71 by the combined application of $100 \%$ Gypsum +4 tha $^{-1}$ FYM and to 7.84 by the application of $100 \%$ gypsum +8 tha $^{-1}$ FYM respectively. The reduction in soil $\mathrm{pH}$ observed due to combined application of gypsum either with FYM was in agreement with earlier findings of Haynes and Naidu (1998) who reported reductions in soil $\mathrm{pH}$ due to combined application of gypsum with farmyard manure.

The combined application of FYM and gypsum lowered the value of exchangeable sodium and exchangeable sodium percentage of the soil. Accordingly, exchangeable sodium was decreased from the initial value of 9.89 to 7.19 at the combined application of FYM@ 4 tha $^{-1}+$ gypsum@100\% and to 7.24 at the combined application of FYM@8 tha ${ }^{-1}+$ gypsum@100\% in the soil system (Table 5). ESP was reduced tremendously with the application of FYM, whereas it decreased slightly with other treatments. The best ameliorative response of gypsum compared to other treatments may be attributed to its rich calcium content which also help in the management of sodium saturated soils as reported by (Suriyan etal., 2011).

This may be due to the fact that gypsum provided $\mathrm{Ca}^{2+}$ to replace the sorbed $\mathrm{Na}^{+}$and the manure would have further boosted the process by producing organic acids and $\mathrm{CO}_{2}$ to dissolve native $\mathrm{CaCO}_{3}$ to liberate more $\mathrm{Ca}^{2+}$ for replacement of $\mathrm{Na}^{+}$. This is in line with the findings of Singh (1985) and Tiwari and Jain (1992). The combined application of FYM@4 tha ${ }^{-1}+$ gypsum@100\% and FYM@ 8 tha $^{-1}+$ gypsum@100\% were also decreased the amount of exchangeable sodium percentage of the soil as compared to the other treatments (Table 5). Electrical conductivity of the soil was raised by gypsum application while decreased with other treatments. The highest EC was recorded in the treatment receiving sole application of gypsum @100\% GR (Table 5). Increase in EC could be attributed to the higher amount of salts contributed by the inorganic NPS fertilizers which was uniformly added through soil application. The addition of organic amendments also influenced the electrical conductivity of soil. It was observed that the application of FYM was more effective than gypsum in reducing soil EC. This is in line with Singh et al. (2015). 
Table 5. Effect of FYM and gypsum amendments on saline sodic soil characteristics

\begin{tabular}{|c|c|c|c|c|c|c|c|}
\hline \multirow[t]{2}{*}{ Treatments } & \multirow[t]{2}{*}{ pHe } & \multirow[t]{2}{*}{ ECe } & $\mathrm{Ca}+\mathrm{Mg}$ & $\mathbf{N a}$ & $\mathbf{K}$ & \multirow[t]{2}{*}{$\operatorname{ESP}(\%)$} & \multirow[t]{2}{*}{$\mathrm{CEC}\left(\mathrm{cmol}(+) \mathrm{kg}^{1}\right)$} \\
\hline & & & \multicolumn{3}{|c|}{$\left(\mathrm{cmol}(+) \mathrm{kg}^{1}\right)$} & & \\
\hline Control & 8.53 & 4.20 & 42.21 & 9.87 & 1.02 & 20.10 & 49.12 \\
\hline $50 \% \mathrm{GR}$ & 8.47 & 4.28 & 42.59 & 9.51 & 0.94 & 19.19 & 49.45 \\
\hline $100 \%$ GR & 8.17 & 4.34 & 43.15 & 9.42 & 0.88 & 18.45 & 51.01 \\
\hline 4 tha $^{-1}$ FYM & 8.19 & 4.03 & 41.04 & 9.38 & 0.82 & 17.90 & 52.41 \\
\hline 4 tha $^{-1} \mathrm{FYM}+50 \%$ GR & 8.13 & 4.17 & 41.21 & 9.04 & 0.85 & 17.22 & 52.49 \\
\hline 4 tha $^{-1}$ FYM $+100 \%$ GR & 7.71 & 4.24 & 41.28 & 7.19 & 0.89 & 12.87 & 55.87 \\
\hline 6 tha $^{-1}$ FYM & 8.13 & 3.84 & 41.18 & 9.33 & 0.97 & 18.30 & 51.00 \\
\hline 6 tha $^{-1} \mathrm{FYM}+50 \% \mathrm{GR}$ & 8.13 & 4.18 & 41.27 & 9.02 & 0.85 & 17.20 & 52.49 \\
\hline 6 tha $^{-1}$ FYM $+100 \%$ GR & 8.07 & 4.20 & 42.07 & 7.84 & 0.94 & 14.76 & 53.13 \\
\hline 8 tha $^{-1}$ FYM & 8.19 & 3.51 & 41.08 & 9.12 & 0.88 & 17.15 & 53.18 \\
\hline 8 tha $^{-1}$ FYM $+50 \%$ GR & 8.07 & 4.20 & 41.30 & 8.18 & 0.89 & 15.73 & 52.01 \\
\hline 8 tha $^{-1}$ FYM $+100 \%$ GR & 7.84 & 4.22 & 41.32 & 7.24 & 0.97 & 13.18 & 54.94 \\
\hline Mean & 8.14 & 4.11 & 41.64 & 8.76 & 0.91 & 16.84 & 52.26 \\
\hline
\end{tabular}

$\mathrm{pHe}=$ soil reaction, $\mathrm{ECe}=$ soil electrical conductivity, $\mathrm{ESP}=$ exchangeable sodium percentage, $\mathrm{CEC}=\mathrm{cation}$ exchange capacity

The results of the present study showed that regardless of the grain yield and yield components of sorghum, the importance of the amendments to physical and chemical properties of the saline sodic soils tested were used. Accordingly, taking in to consideration to both the yield of sorghum and the value of the amendments to saline sodic characteristics, 4 tha $^{-1} \mathrm{FYM}+100 \%$ GR followed by 8 tha $^{-1} \mathrm{FYM}+100 \%$ GR were recommended for yield and yield component maximization and reclaiming of the saline sodic soils in Raya Alamata district.

\section{Conclusion and Recommendation}

Soil salinity/sodicity is an increasing problem in the world and main obstacle to agricultural productivity. The increasing distribution of salt affected soils in all continents minimizes the productivity of soil resources. Therefore, developing a strategy to amend those soils to attain food self-sufficiency and reverse ecological degradation for agricultural sector is mandatory. The findings confirmed that soil salinity/sodicity significantly limit crop production and the consequences are damaging in both socioeconomic and environmental terms. Therefore, combined application of farmyard manure with gypsum ( 4 tha $^{-1} \mathrm{FYM}+100 \%$ GR) followed by 8 tha $^{-1}$ FYM $+100 \%$ GR as amendment were the best compared to the others in improving of soil properties and yield and yield attribute of sorghum in saline sodic soils of Raya Alamata district. More beneficial influences were noticed by extending the applications to the last year of cropping system. However, the research was conducted for a specific site and hence, repeating the experiment in space and time is necessary so as to improve the validity of this finding and acceptance for agricultural producers.

\section{Acknowledgements}

The authors are grateful to Ethiopian Institute of Agricultural Research (EIAR), for providing funds for the experiment. The authors also truthfully appreciate to Mekhoni Agricultural Research Center (MeARC) staff members for their technical assistance and kind cooperation during field experimentation and data collection.

\section{References}

Amanuel Zenebe, Girmay Gebresamuel and Atkilt Girma. 2015. Characterization of Agricultural Soils in CASCAPE Intervention Woredas in Tigray Region. Mekelle, 58-64.

Amanullah M.M. 2008. Response of lowland rice varieties to reclamation practices in coastal saline soils. Journal of Applied Science Research, 4:871-874.

Birhane Hailu, Lemma Wogi and Solomon Tamiru. 2019. Assessment of Soils of Waterlogged Areas in Relation to Salinity and Sodicity in Irrigated Low Land Soils of Raya Valley, Northern Ethiopia, International Journal of Research and Innovations in Earth Science 6 (2): 2394-1375.

Birhane Hailu. 2018. Salinity status of soils of irrigated lands, water logged areas and irrigation water quality at Raya Alamata district, northern Ethiopia. A Thesis submitted to Haramaya University, Haramaya, Ethiopia.

Cheraghi, S., Heydari, N., Qadir, M. and Oweis, T. 2006. Improving Crop Growth and Water Productivity on Salt-affected Soils. Research Report, 12-18.

CSA (Central Statistical Agency). 2015. Agricultural sample survey. Statistical bulletin 578 May, 2015, Addis Ababa, Ethiopia.

FAO (Food and Agricultural Organization). 1988. Salt Affected Soils and Their Management. FAO Soils Bulletin 39, Rome, Italy.

Ghafoor, A and. Muhammad, S. 1990. Reclamation of a saline sodic soil as a function of gypsum particle size 
and water quality. Proceeding. $2^{\text {nd }}$ National Soil Science. Congress, Dec. 20-22, 1988, pp. 85-90.

HAQ. I, Khattak. S, rahman, A. and Salim, M. 2001. Effect of Various Amendments on the Yield of Rice Crop under Saline-Sodic Conditions in Mardan/Swabi Districts. International Journal Of Agriculture \& Biology, 3(3): 289-291.

Haynes R, Naidu R. Influence of lime, fertilizer and manure applications on soil organic matter content and soil physical conditions: A review. Nutrient Cycling in Agro ecosystems, 1998; 51:123-137.

Makoi J.H.J. and Ndakidemi P.A. 2007. Reclamation of sodic soils in northern Tanzania, using locally available organic and inorganic resources. African Journal of Biotechnology Vol. 6 (16), pp. 1926-1931.

Mokoi J.H.J., Verplancke H. 2010. Effect of gypsum placement on the physical properties of a saline sandy loam soil. Australian journal of crop science 4: 556-563.

Mullins C.E., Mackleod D.A., Northcote K.H., Tidsdall J.M., and Young J.M. 1990. Hardsetting soils. Behaviour, occurrence and management. Adv. Soil Sci. 11:37-108.

Nata Tadesse, Dessie Nedaw, Kifle Woldearegay, Tesfamichael Gebreyohannes and Steenbergen, V. 2015. Groundwater Management for Irrigation in the Raya and Kobo Valleys, Northern Ethiopia. International Journal of Earth Sciences and Engineering, 8 (3):36-46.

Qadir M., Tubeileh A., Akhtar J., Larbi A., Minhas P.S., and Khan M.A. 2008. Productivity enhancement of saltaffected environments through crop diversification. Land Degrad Dev 19:429-453

Richards L.A. 1954. Diagnosis and improvement of saline and alkali soils. U.S. Dept. Agric. Handbook No 60.

RVLZ (Raya Valley Livelihood Zone). 2007. Raya valley sorghum and Teff lively hood zone, Tigray Region, Ethiopia.

Sadiq M, Hassan G, Mehdi SM, Hussain N, Jamil M. 2007. Amelioration of saline sodic soil with tillage implements and sulphuric acid application. Pedosphere. 17 (2):182-190.

Singh MV. Effect of Gypsum and Farmyard Manure on the Yield af Rice and Wheat in a Saline-Sodic Soil. CSSRI Annual Report. Central Soil Salinity Research Institute, India, 1985.

Singh, J. Athokpam, S, Devi, K, Chongtham N, and Singh E.2015. Effect of farm yard manure and gypsum on fertility status of alkaline soil under maize- wheat cropping sequence. African Journal of Agriculture Resource. 10(24):2421-2431.

Suriyan Cha-um, Pokasombat Yuthasak, Kirdmanee Chalermpol. 2011. Remediation of salt-affected soil by gypsum and farmyard manure -Importance for the production of Jasmine rice. Australian journal of crop science. AJCS 5(4):458-465.

Tekle,Y., and Zemach ,S. 2014. Evaluation of Sorghum (Sorghum bicolor (L.) Moench) varieties for yield and yield Components at Kako, Southern Ethiopia. Journal of Plant Science 2(4):129-133.

Tenalem Ayenew, Merhawi Gebreegziabher, Seifu Kebede and Sileshi Mamo. 2013. Integrated assessment of hydrogeology and water quality for ground water based irrigation development in the Raya Valley, northern Ethiopia. Water International, 38(4):480-492.

Tiwana, H., Malik, K. and Mahmood, Y.1997. Effect of FYM and gypsum on the yield and quality of sugarcane (Cv. BF- 1 62). Pakistan Journal of Soil Science., 13(5): 88-91.

Tiwari SK, Jain BL. Relative efficiency of gypsum, farmyard manure and pyrites under percolation conditions in reclamation of alkali soil. Ann. Agric. Res. 1992; 17:44-49.

USSLS (United State Salinity Laboratory Staff). 1954. Diagnosis and improvement of saline and alkali soils. Agriculture Hand book 60, USDA, Washington DC.

Wong V.N.L., Dalal R.C. and Greene R.S.B. 2009. Carbon dynamics of sodic and saline soil following gypsum and organic material additions: A laboratory incubation. Appl Soil Ecol 41:29-40. 